\title{
DECLINE OF RENTAL HOUSING IN INDIA: A Case Study of Mumbai
}

+SAHIL GANDHI, VAIDEHI TANDEL, SHIRISH PATEL, ABHAY PETHE, KABIR AGARWAL AND SIRUS J. LIBEIRO

\begin{abstract}
Rental housing in India has witnessed a significant decline over the years. This could be attributed to various reasons including the nature of the rent control laws. The rent control law in Mumbai has created a shortfall in formal, affordable rental housing and, at a broader level, has contributed to the distortions in the land market. The nature of the 'first generation' rent control in Mumbai is such that it has led to the deterioration of the existing rental housing stock and virtually halted the construction of new housing for rental for the city. It has also given rise to informal practices such as 'pagdi' or key money. This paper assesses the impact of rent control for Mumbai. In particular, it analyzes the spatial concentration and composition of rent controlled tenements in the city. It then proposes reforms that would allow a gradual move towards rationalized rent controls. It argues that second generation controls will help incentivize investments in the rental housing segment and hence reduce the demand pressure on the housing market at large, with implications for prices and affordable housing in particular.
\end{abstract}

CONTACT

Vaihedi Tandel

IDFC Foundation

vaidehi.tandel@gmail.com

\footnotetext{
Sahil Gandhi was a Ph.D. scholar at Department of Economics, University of Mumbai at the time of the study, and is now a Consultant at Indian Council for Research in International Economic Relations (ICRIER). Vaidehi Tandel is Associate Vice President at IDFC Foundation. Shirish Patel is a civil engineer and urban planner, one of the three original authors of the idea of New Bombay, who was in charge of the new city's planning, design and execution for its first five years. Abhay Pethe is Chair Professor, Vibhooti Shukla Centre, Department of Economics, University of Mumbai. Kabir Agarwal is Researcher at the Department of Economics, University of Mumbai. Sirus Joseph Libeiro was a Research scholar at Department of Economics, University of Mumbai at the time of the study, and is now a Research Associate at ICRIER. The authors would like to thank Mr. Vidyadhar Phatak for extensive comments and suggestions. All views expressed are personal and any errors or omissions are the responsibility of the authors alone.
} 


\section{INTRODUCTION}

Rental housing is one of the key features of vibrant housing markets and an essential component of affordable housing.

However, housing in India has come to be dominated by ownership tenure, with formal rental housing, especially in the northern parts of the country, languishing. This could be attributed to various reasons, including the nature of existing rent control laws. In Mumbai, the draconian rent control law is one of the factors contributing to shortage in formal affordable housing and distortions in the land market. ${ }^{1}$ This law caps rents for protected properties. The cap, called standard rent, is arbitrarily determined (set at approximately 12.5 percent return on cost of construction plus cost of land at the time of construction) and allows for only restricted annual increases in rates which are well below the rate of inflation. There has been near universal consensus that rent controls of the kind seen in Mumbai, known as "first generation rent control", have a devastating impact on rental markets and, in general, housing and land markets in cities. Many cities the world over have either abandoned rent controls completely or have adopted more rational "second generation" policies for regulating rents. Rent control in Mumbai has been particularly damaging for the housing market, which is characterized by ownership dwellings constructed mainly for the upper middle class on the one hand and a high incidence of slums housing the majority of the population on the other. It neglects considerations regarding inflation rates, incentives for maintenance of rental property, and providing decent returns to landlords. As a result, there has been a dilapidation of existing rent-controlled residential properties, and a virtual halt to new investment in rental housing provision (Patel 2005, 2013). At a broader level, rent control has exacerbated the problem of inadequate affordable housing, immobility of tenants, and produced a mismatch between house prices and household incomes (see Gandhi 2012).

The recently introduced Rajiv Awas Yojana, a centrally sponsored scheme for a "slum free India", requires that the existing rent control laws be amended so that new rental housing stock can be created and so that rents can be governed by the market. Thus, in the light of the existing situation and the central government mandate, it is imperative to review the rental law for Mumbai and suggest reforms.

1 Other important factors include its peculiar topography (Bertaud 2011), absence of effective efforts to gain access to more land mass, mismanagement of land owned by government authorities (Pethe et. al. 2012, Rajack et al. 2013), and restrictive land regulations (Phatak 2002)
This paper argues that there is an urgent need to reform the existing rent controls in Mumbai in order to address one of the many constraints affecting land markets. The objective of such reform would be to revive the rental housing market. This requires strategies for freeing up and upgrading the existing rental stock, and incentivizing investments in rental housing by ensuring adequate returns. For the strategies to be politically acceptable and implementable, they must consider the interests of all the relevant stakeholders.

The paper first outlines the theoretical arguments against rent control and goes on to describe the international experience regarding rent controls and reforms. It examines the situation of rental housing in India particularly in relation to the growth in urban workforce participation, urbanization, population, and per capita incomes. It traces the rent control laws in Mumbai and highlights the lacunae therein. A snapshot of housing in Mumbai under rent and ownership is provided for illustrating the decline in the rental housing market. Finally the paper discusses possible ways in which the extant rent controls in Mumbai could be reformed.

\section{THEORETICAL ARGUMENTS AGAINST RENT CONTROL}

There has been considerable debate among social scientists regarding the possible impact of rent controls in housing markets. Whereas some hold that rent controls have certain advantages, the overwhelming opinion has been that rent controls have a detrimental effect on cities. The arguments against rent controls presented here are based on Jenkins (2009) and Block and Olsen (1981). These can be classified as follows:

IMPACT ON HOUSING MARKETS

Rent controls freeze rents at a particular level, which distorts the rental housing market. The distortion increases as the gap between frozen rent and market rent widens. Rent controls are a form of subsidy, extracted from landlords, and paid to tenants. They discourage the supply of new rental housing. The housing shortage results in excess demand (seen as vacancy rate that is below a certain natural vacancy rate, which fluctuates between $5 \%$ and 10\%). Following a housing shortage, increased search costs for those looking for rental housing amplify the inefficiencies. Informal practices and black markets thrive in the presence of 
stringent rent controls. Since landlords do not get a reasonable return on their property, they have no incentive to invest in the maintenance of the tenanted property, resulting in a degradation of the existing rental housing stock, and eventually, possible depletion. $^{2}$

CONSIDERATIONS OF EQUITY

Contrary to the notion that rent controls would always result in redistribution of resources favoring the poor, it is seen that over time rent controls can certainly have inequitable effects. Fortunes change. It can happen that tenants who occupy the rent-controlled apartments come to be wealthier than their landlords. But they continue to enjoy a rental subsidy from their landlords. And it is not a trivial subsidy. In Mumbai standard rent can be one-thousandth, or less, of the prevailing market rent.

Rent control is also inequitable as it benefits only those who are fortunate enough to be living in the regulated properties. For newcomers, it is harder to find affordable rental housing because no new rental housing is being constructed. As the city grows, for the low-income groups particularly, this leads to a worsening of their situation and could result in homelessness and slums. When rents are regulated, landlords may resort to other nonprice means of rationing. This may result in discrimination against certain social groups and thus result in greater segregation.

\section{BROADER ECONOMIC EFFECTS}

Rent control reduces labour mobility, as those living in rentcontrolled units are unwilling to move out because they will lose protection. The unwillingness to move closer to places of employment results in inefficient use of resources and time, which are spent on longer commutes. Rent controls also considerably affect public finances through revenues as well as expenditures. Revenues are reduced as property tax collections fall below potential. This happens when property taxes are assessed on rental values and capping. of rents results in a reduction of the tax base. Given the absence of affordable rental housing provided in the market, public resources would have to be used to create affordable housing. This is not only a strain on the public finance of the

2 Some economists argue that rent controls do not affect maintenance. For instance, Moon and Stotsky (1993) opine that tenants are also likely to contribute to the maintenance of the property, offsetting the landlords' neglect. Casual empiricism suggests that some buildings in the island city under rent control, particularly those with large apartments, are well maintained. However, many rent controlled properties are in a dilapidated condition. government, but is an inefficient expenditure, as it does not result in any productivity increases.

Despite the wide consensus that rent control is a misguided policy, there is no political will to remove it. This is due to the fact that the protected tenants are a strong and large group, mostly middle-class and quite vocal, and also because abolishing rent controls could be projected as being anti-poor, whether in fact it is so or not.

\section{INTERNATIONAL EXPERIENCE OF RENT CONTROLS}

Many countries have at some point in time imposed rent controls in order to protect tenants from unbridled rents. While several countries have abandoned what are called first-generation rent controls, some continue rent controls in a modified form, called second-generation rent controls. The success of rent controls or their repeal depends upon various factors such as the nature of housing markets, specific design of legislation of rent control, and indigenous conditions. This section provides a review of rent control practices in developing and developed countries.

NEW YORK CITY, USA ${ }^{3}$

New York City has had a long history of regulating rents and has had a complicated legal framework for rental housing units. Rent controls were first introduced in the city during the Second World War through a federal law that froze rents in order to protect tenants from galloping inflation. After the war, the federal law was dissolved and in the State of New York it was replaced with a state law for rent control, applicable to buildings with six or more apartment units built before 1947. It froze rents to levels prevailing in 1947. Post 1950s, decontrol in a measured way was opted for by the State. Till 1962, rent control in New York City was subject to the State law. In 1962, New York City was allowed to frame its own rent control programs under the Local Emergency Rent Control Act. There was a phased decontrol in New York City between 1964 and 1968.

In 1969, the Rent Stabilization law was passed by New York City following economic hardships and escalating rents in the unregulated sector. About 400,000 apartments in New York City were brought under rent stabilization. Of these around 325,000 apartments had been constructed post 1947 and the rest were

3 The account of Rent controls in New York city is primarily based on two web sources: http://www.tenant.net/Oversight/5oyrRentReg/history.html (accessed on 16 Dec 2012) http://furmancenter.org/files/publications/HVS_Rent_Stabilization_fact_sheet_FINAL_4.pdf(accessed on 16 Dec 2012) 
formerly rent-controlled apartments that had been decontrolled. A Rent Guidelines Board was created in order to regulate the rent increases. In order to ensure that the rents of regulated units reflected the costs of maintenance, a Maximum Base Rent (MBR) was set up under the New York City Local Law (30) in 1970. The MBR is calculated based on factors such as real estate taxes, water and sewerage charges, operating and maintenance costs, return on capital value, and vacancy and collection loss allowance. ${ }^{4}$ It is revised biennially depending upon conditions in the housing market. Rents of controlled properties are revised upwards till they reach the MBR. However, in order to prevent a sudden hike, growth rate of rents below MBR has a ceiling of $7.5 \%$ per annum (this is at a time when inflation is running at 1.1\%). Economic hardships following the Vietnam War, and several reports that highlighted the negative impacts of rent decontrol in the New York State, resulted in the enactment of the Emergency Tenant Protection Act in 1974. This Act also amended the New York City Rent Stabilization Law, thereby overriding the city's legislation. According to the Act, buildings in New York City that were completed between 1969 and 1973 were to be placed under rent stabilization. Moreover, deregulated buildings were once again brought under rent stabilization. In 1984, administration of rent control and rent stabilization programs was transferred back to the State. The Rent Regulation Reform Act that was passed in 1993 took some steps towards the decontrol of regulated rental units. In particular, vacant apartments and occupied regulated units that became vacant were decontrolled. The Act also sought to decontrol high rent apartments that were occupied by highincome households, upon application by the owner. In order to verify incomes of households, the assistance of the New York State Department of Taxation and Finance was sought. It was the first attempt in New York to apply a means test to determine eligibility of the tenant household for rent protection. The latest in the long list of rent laws is the Rent Act of 2011. The salient features of this Act include limiting rent increases on vacancy to once a year, provisions for increasing the regulated rent upon improvements on buildings, and for deregulation of vacant and high income regulated units. ${ }^{5}$

According to a recent factsheet by the Furman Center for Real Estate and Policy (2011), New York City is predominantly a rental

4 http://www.nyshcr.org/Rent/FactSheets/orafac22.htm

5 http://www.nyshcr.org/Rent/RentAct2011.htm (accessed on 11th May, 2013). market with around 68 percent rental units. The rent controlled units amount to 1 percent of the total units whereas rent stabilized units account for about 31 percent. A further 27 percent of housing units were rentals at market rates and 9 percent were other rental units such as public housing, and loft board regulated units, among others. The factsheet also reveals that barring Manhattan, the difference between the stabilized and market rents in other parts of New York is not very large. While median incomes of those living in uncontrolled rental units are higher than those in stabilized units, those in the stabilized units do not necessarily belong to low-income groups. Except for Staten Island, the rent to income ratio for stabilized units is higher than those in uncontrolled units, albeit by a narrow margin.

ZURICH, SWITZERLAND

Werczberger (1997) provides an account of the rent control situation in Switzerland. Rent controls have existed in Switzerland since the First World War and continue to exist even today. However, the current regime of rent controls belongs to the "second generation". These rental regulations allow for rent increases to cover maintenance costs and account for inflation as well as provide normal profit for owners. However, there is no vacancy decontrol; a new tenant can approach the courts for protesting excessive rents. The housing market in Zurich is peculiar with a high proportion of rented apartments; the proportion of ownership was around 34 percent in 1998 (Bourassa and Hoesli 2010). The reasons for high preference for rental housing could be attributed to two factors: expensive ownership on account of high house prices because of high construction quality standards, limited land for development, stringent mortgage underwriting criteria, and heavy taxation of the owner occupied houses (ibid.); and the rent regulation laws which have managed to not allow exorbitant rents while maintaining the profitability of providing rental housing. Most rental units are privately provided. Consistently low inflation (below 2 percent in the last 15 years) has been one of the key reasons why rental markets continue to be able to function efficiently despite rent regulations in Zurich.

GEORGETOWN, MALAYSIA ${ }^{6}$

Georgetown, the capital city of the state of Penang in Malaysia, is a port city known for its urban heritage. Rent control in the

6 The review of Georgetown provided in this section is based on Lee et.al. (2008). 
city existed since after the Second World War but the main law that was applicable to the city was the Control of Rent Act of 1966. Under the regime of rent control, rentals were extremely low and many of the rental properties were occupied by tenants from low-income groups. Illegal practices of sub-letting and transferring tenancies by paying a fee divided among the landlord and existing tenant were extremely common. In the latter cases, the fees for tenancy transfer were as high as the price for a house in the suburbs. In 2000, the rent control was completely repealed, with no safeguards for the tenant population, which was earlier protected under the law. This resulted in rapid increases in rents and high incidences of evictions. Over the years many of the poorer tenants left the city. The redevelopment that was expected to take place after the repeal did not take place since during the same period the economy was in a downturn. Today, much of the inner city of Georgetown has commercial establishments and not much of a population of low-income groups. There is talk of introducing rent controls once again to attract the young ${ }^{7}$, working population to live in the city. The experience of Georgetown brings to light the damaging consequences of a sudden repeal of rent control in a city.

MANILA, PHILIPPINES ${ }^{8}$

As in most parts of the world, rent controls in Manila were first introduced in the post World War period. The controls were phased out after the War but were re-introduced in the 1970s and implied a total freeze on residential rents that were less than USD 6 per month. ${ }^{9}$ In 1985 , the country shifted to a regime of secondgeneration rent controls, which permitted increases in rents to account for inflation and exempted newly constructed residences from rent controls altogether. In 2001, approximately 96 percent of the total renter households were protected under rent control. Ballestros (2001) observes that since most of the rent-controlled units are occupied by low-income households, the controls

benefit the poor. She also finds that long-term tenants are more likely to enjoy the benefits of protection rather than those who live as tenants for a short duration. The rent control acts have usually been enacted for a specific duration. The latest act is the Rent Control Act of 2009, which is applicable till 2013. The Act is applicable to residences with a monthly rental of or below USD 200 in the National Capital Region, and below USD 100 in other areas. It stipulates that rents cannot be increased by more than 7 percent $^{10}$ and cannot be increased by more than once in a year. In the case of units that are vacant, there is no maximum limit for increasing rent. The rent control laws also recognize rent-to-own agreements between tenant and landlord.

\section{CAIRO, EGYPT}

Malpezzi (1998) provides a review of rent control laws up until 1996. According to him, rent controls were first introduced in 1944 and applicable to houses set up before 1944. Over time, these were extended to other rental units and by 1962 they were

Table1: Inter-city Comparison of Rent Regulations and Characteristics of Rental Housing

\begin{tabular}{|c|c|c|c|c|c|c|c|}
\hline CITY & $\begin{array}{l}\text { YEAR } \\
\text { (1st generation } \\
\text { rent control) }\end{array}$ & $\begin{array}{l}\text { YEAR } \\
\text { (2nd generation } \\
\text { rent control) }\end{array}$ & $\begin{array}{l}\text { YEAR } \\
\text { (rent control } \\
\text { repeal) }\end{array}$ & $\begin{array}{l}\text { RENTAL } \\
\text { HOUSING \% } \\
\text { (total housing) }\end{array}$ & $\begin{array}{l}\text { RENTAL } \\
\text { HOUSING \% } \\
\text { (rent control) }\end{array}$ & $\begin{array}{l}\text { RATIO OF } \\
\text { HOUSING } \\
\text { (formal market) }\end{array}$ & $\begin{array}{l}\text { RATIO OF } \\
\text { iNCOMES } \\
\text { (controlled rent) }\end{array}$ \\
\hline New York & 1943 & 1969 & 2013 & 68 (2011) & 32 (2011) & 100 & 3 \\
\hline Zurich & WWI & 1972 & 2013 & 66 (1998) & & 100 & $6(1998)$ \\
\hline Manila & WWII & 1985 & 2013 & & 96 (2011) & $35(2002)$ & 15 (1998) \\
\hline Cairo & 1944 & 2013 & & $50(2008)$ & 78 (2008) & $56.5(2008)$ & \\
\hline Mumbai & 1947 & 2013 & & 18 (2010) & 92 (2010) & 59 (2011) & \\
\hline
\end{tabular}

Figures in parenthesis are years.

*Presently, the rental housing is regulated under the Rent Law No. 4 of 1996.The figures for Cairo have been taken from a sample survey conducted by USAID and TAPRII.

\# Presently, the rental housing is regulated under the Maharashtra Rent Control Act of 1999.

Sources: New York: http://www.tenant.net/Oversight/50yrRentReg/history.html, Furman Center for Real Estate and Policy (2011)

Zurich: Bourassa and Hoesli (2010), Werczberger (1997)

Manila: Ballestros (2001), http://www.ucl.ac.uk/dpu-projects/Global_Report/pdfs/Manila.pdf

Cairo: (Malpezzi 1998), USAID and TAPRII (2008)

Mumbai: Census of India 2011, Authors' calculations

7 http://www.pulaupinang.com/2012/10/rent-control-act-to-attract-young-blood/ (accessed on 19th December 2012).

8 This section is based on Ballestros (2001).
9 Conversion Rate: 1 PHP $=0.02$ USD

10 The mean inflation rate in Philippines for the year 2010 was 3.8 percent. 
applied to both new and existing rental units. In 1981, the rents were set at 8 percent of the land value and construction $\operatorname{cost}^{11}$. Incentives for up gradation of the rental stock were built into the provision, which stated that in case of renovation, the rents would be reassessed (Malpezzi 1998). Maintenance and repair costs were to be shared by the landlords and tenants (ibid.). The practice of key money, or payments made to the landlord and outgoing tenant before moving in, is prevalent in Cairo. The $1980 \mathrm{~s}$ saw a construction boom in Cairo, particularly in the high-end segment owing to high returns on investment, while the lower end remained undersupplied (Fahmi and Sutton 2008). The provisions in the rent control laws were not enough to incentivize owners to rent and resulted in nearly 50,000 vacant units (ibid.). In the 1990s, nearly 70 percent of the households resided in rental units; of which one third were in the formal market and two thirds were in the informal market (Malpezzi 1998). According to Malpezzi (1998), much of the new ownership and rental construction has been in the informal market. In 1996, rent control legislation was passed that ended inheritance of rent protection, specified that contracts between landlords and tenants be made for a limited period of time and allowed for rents to be increased annually by 10 percent $^{12}$ consecutively for five years and subsequently to be taken over by the market (Fahmi and Sutton 2008). The law however largely worked against the poor as there was no security of tenure and the rents were prohibitively high (see Mansour 2009). A study by Makary (2002) reveals that 6 percent of the vacant houses in Cairo were owned by households themselves living in rentcontrolled apartments. The general experience of Cairo regarding rent control has been that controls have been excessive resulting in undersupply of rental housing, poor maintenance of rental units, no protection of low income households, and informal practices such as key money as well as informal housing.

Table 1 provides a comparison of rent regulations and characteristics in different cities in respect of formal housing.

As seen from the table, Cairo and Mumbai have yet to shift to a regime of second generation rent control. It is clear that New York and Zurich, which have moved to second generation rent controls, have a higher proportion of rental housing in the housing market as compared to Mumbai and Cairo.

Table 2 provides a comparison of rental regimes and share of slum population across cities in developing countries. Cape Town is the only one among the selected cities to have repealed rent control, while Manila has moved to second generation rent controls. Both have relatively lower proportions of their populations living in slums. The share of slum population is highest in Nairobi and Mumbai, where rental laws have yet to move to the second generation kind. Cairo, where rent controls were removed hastily and where tenants have no protection at all, also has considerably high proportion of slum population.

Table 2: Comparison of rental laws and slum population across cities in developing countries

\begin{tabular}{|c|c|c|c|c|c|c|c|}
\hline CITY & $\begin{array}{l}\text { YEAR } \\
\text { of 1st generation } \\
\text { rent control }\end{array}$ & $\begin{array}{l}\text { YEAR } \\
\text { of current 2nd } \\
\text { rental law }\end{array}$ & $\begin{array}{l}\text { YEAR } \\
\text { of rent control } \\
\text { repeal }\end{array}$ & $\begin{array}{l}\text { Slum population } \\
\text { PERCENTAGE }\end{array}$ & $\begin{array}{l}\text { RENTAL } \\
\text { HOUSING \% } \\
\text { (rent control) }\end{array}$ & $\begin{array}{l}\text { RATIO OF } \\
\text { HOUSING } \\
\text { (formal market) }\end{array}$ & $\begin{array}{l}\text { RATIO OF } \\
\text { iNCOMES } \\
\text { (controlled rent) }\end{array}$ \\
\hline New York & 1943 & 1969 & 2013 & 68 (2011) & 32 (2011) & 100 & 3 \\
\hline Zurich & WWI & 1972 & 2013 & 66 (1998) & & 100 & $6(1998)$ \\
\hline Manila & WWII & 1985 & 2013 & & 96 (2011) & 35 (2002) & 15 (1998) \\
\hline Cairo & 1944 & 2013 & & $50(2008)$ & 78 (2008) & 56.5 (2008) & \\
\hline Mumbai & 1947 & 2013 & & 18 (2010) & $92(2010)$ & 59 (2011) & \\
\hline
\end{tabular}

Figures in parenthesis are years.

${ }^{*}$ Presently, the rental housing is regulated under the Rent Law No. 4 of 1996.The figures for Cairo have been taken from a sample survey conducted by USAID and TAPRII.

\# Presently, the rental housing is regulated under the Maharashtra Rent Control Act of 1999.

Sources: New York: http://www.tenant.net/Oversight/5oyrRentReg/history.html, Furman Center for Real Estate and Policy (2011)

Zurich: Bourassa and Hoesli (2010), Werczberger (1997)

Manila: Ballestros (2001), http://www.ucl.ac.uk/dpu-projects/Global_Report/pdfs/Manila.pdf

Cairo: (Malpezzi 1998), USAID and TAPRII (2008)

Mumbai: Census of India 2011, Authors' calculations 
Figure 1: Relationship between rental regimes and slums

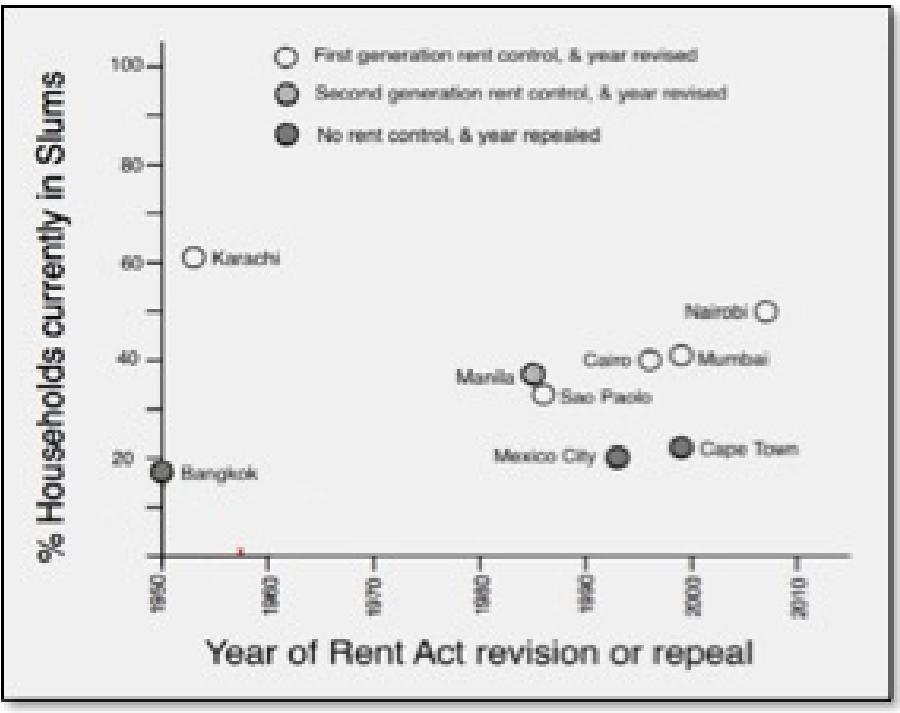

Figure 1 is a graphical representation of the information provided in Table 2. The horizontal axis shows the years in which rent control laws applicable to the different cities were introduced and the vertical axis shows the latest available proportion of slum population. It shows that cities having no rent control laws currently have the lowest shares of population. Karachi, the only city that continues to have unmodified first generation rent controls, has the highest slum population.

a) District-wise urban rental housing in 1961

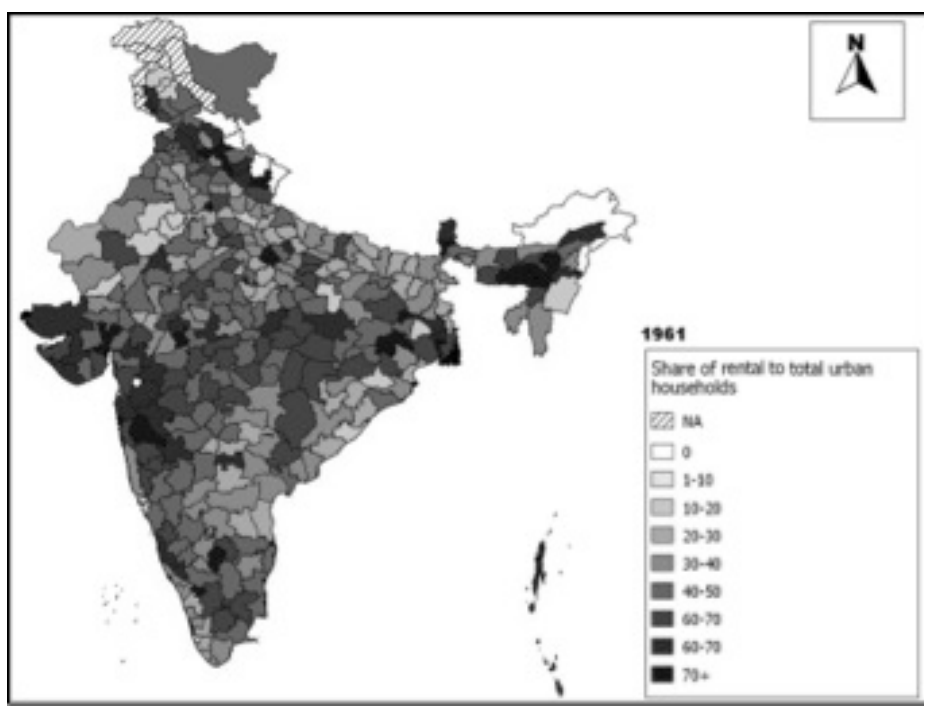

\section{SITUATION OF RENTAL HOUSING IN INDIA}

Rental housing in India has undergone a considerable transformation over the years. To present a comparative picture of rental housing in India, we present the rental situation in 1961 and 2011. We make use of the data collected by the Census of India on housing tenure status. While using this data, it is necessary to add the caveat that collecting information on rental housing is difficult and thus the census figures could be underestimates (Kumar 2001). Also, the census data does not distinguish between formal and informal rental housing. In 1961, housing tenure was classified as "ownership" or "rented" and the data was collected on the basis of a 20 percent sample. The data for the 2011 census on housing tenure is based on a 100 percent survey. In 2011, an additional category called "other" was included. The Census of 2011 defines the category "rented" as a housing unit for which rent is paid or which is contracted for by the household. The category "other" is defined as a housing unit which is provided rent free by an employer to an employee or in the cases of unregularized slums or unauthorized construction where the household does not own the structure or land and pays no rent for habitation. According to the Census, the share of rental housing in total housing for urban India has fallen from 54 percent in 1961 to 31 percent in 2011. For 2011, the share is calculated by combining the categories "rented" and "other". If we exclude the category "other", the share of rental housing to total housing in urban India in 2011 would be 28 percent. Figure 2 shows the proportion of urban rental housing at the district

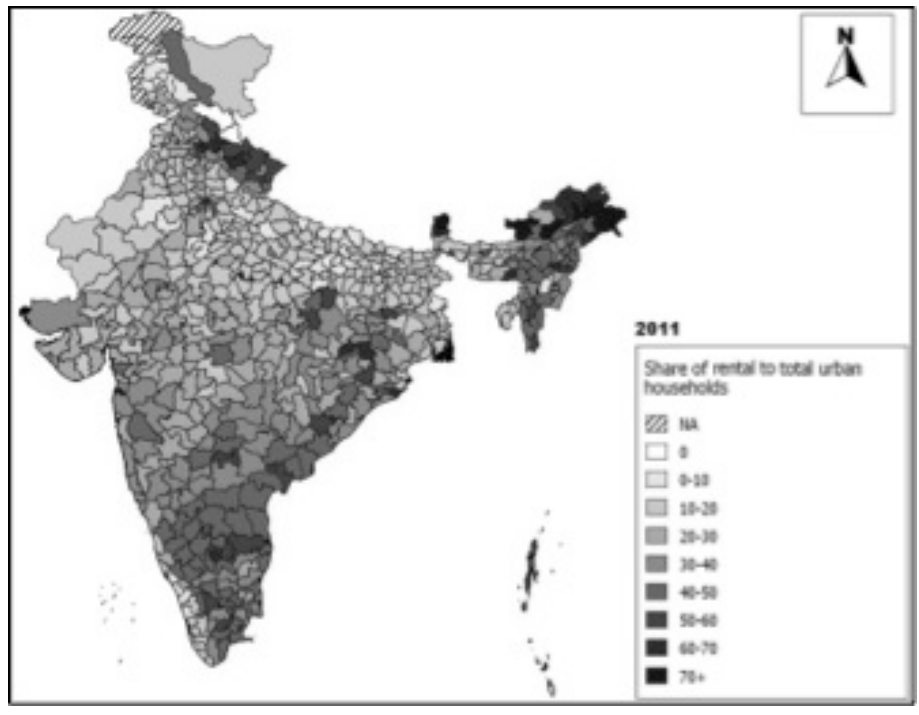

b) District-wise urban rental housing in 2011 
level for the years 1961 and 2011. ${ }^{13}$

From Figure 2, we see that in nearly all parts of the country, the share of rental housing declined between 1961 and 2011. Further, in 2011 there is a clear distinction in the rental housing situation between the north and the south. The share of rental housing in the southern parts of the country is distinctly higher than in the northern parts, except for Himachal Pradesh, Uttaranchal and the extreme North-east. One underlying reason for such a trend could be that states in southern Indian are performing better economically than those in the north (see Paul and Sridhar 2013), and the resulting job creation provides better opportunities and incentives for people to move there.

To understand what factors could affect rental housing in India, we run a basic regression. The dependent variable is taken to be the percentage of rental housing in the urban parts of the states (\%Rent_urban). The independent variables considered are the state-wise urban workforce participation rates (\%urban_working), urbanization $\operatorname{rates}^{{ }^{4}}$ (\%urban_pop), log of the population (log_pop), and the log per capita Net State Domestic Product (NSDP) (log_PCNSDP). To increase the number of observations, we make use of decadal data from 1961 to 2011. For data on percentage of rental housing, urban working population, urban population, and total population, we make use of the Census of India. For data on the state-wise per capita NSDP, we make use of data published by the Economic and Political Weekly Research Foundation. We run the first regression with the entire sample of states ${ }^{t_{5}}$ and the second regression with the 14 major states $^{16}$, which comprise more than 85 percent of the population and total Gross Domestic Product (Dash and Raja, 2012). The results of the regression are given in Table 3 .

The results show that '14 Major States' has a better fit than 'All States'. In the former \%urban_working, log_pop, and log_PCNSDP are statistically significant. Urban workforce participation rates and share of urban population have a positive impact on share of urban rental housing whereas the development of the state (as shown by log per capita NSDP) and its total population has a negative impact. In the latter, all

Table 3: Regression Results

DEPENDENT VARIABLE: \% RENT_URBAN

\begin{tabular}{|c|c|c|}
\hline \multicolumn{2}{|r|}{ ALL STATES } & 14 MAJOR STATES \\
\hline \multirow[t]{2}{*}{ INTERCEPT } & $67.9235^{* * *}$ & -16.8162 \\
\hline & $(16.6706)$ & $(29.0161)$ \\
\hline \multirow[t]{2}{*}{$\%$ URBAN_WORKING } & $1.2717^{* * *}$ & $1.5057^{* * *}$ \\
\hline & $(0.3221)$ & $(0.4370)$ \\
\hline \multirow[t]{2}{*}{$\%$ URBAN_POP } & 0.00028 & $0.4287^{* *}$ \\
\hline & $(0.0548)$ & $(0.1920)$ \\
\hline \multirow[t]{2}{*}{ LOG_POP } & $-5.293464^{* * *}$ & $7.5340 *$ \\
\hline & $(1.6298)$ & $(3.8095)$ \\
\hline \multirow[t]{2}{*}{ LOG_PCNSDP } & $-7.94410^{* * *}$ & $-16.7335^{* * *}$ \\
\hline & $(1.9830)$ & $(1.9924)$ \\
\hline $\mathrm{R}^{2}$ & 0.2886 & 0.5729 \\
\hline ADJUSTED R ${ }^{2}$ & 0.2700 & 0.5507 \\
\hline OBS. & 158 & 82 \\
\hline
\end{tabular}

ROBUST STANDARD ERRORS ARE IN PARENTHESIS

* SIGNIFICANT AT 10\%

** SIGNIFICANT AT $5 \%$

*** SIGNIFICANT AT $1 \%$

13 Since the district map of 1961 was not available, we created a new shape file for districts in 1961 us ing GIS software and the 2011 district shape file that comprised all the relevant districts.

14 As per the census, workforce participation rate is defined as share of workers in total population. We calculate state-wise workforce participation rate as share of urban workers in total urban population.
15 We exclude the observations with missing data points. The total number of states is 28. 16 The 14 states are Andhra Pradesh, Bihar, Gujarat, Haryana, Karnataka, Kerala, Madhya Pradesh, Maharashtra, Orissa, Punjab, Rajasthan, Tamil Nadu, Uttar Pradesh, and West Bengal. 
variables are statistically significant. The sign of log_pop changes from negative in the case of 'All States' to positive for '14 Major States'. ${ }^{17}$

Having examined the situation in the states, we analyze the rental housing situation in Indian cities. Since city level data is not available, we make use of the district level urban data from the relevant census years. The sample of cities selected for representation in Table 4 includes five cities with the highest growth in the share of rental housing and five with the lowest growth in the share of rental housing between 1961 and 2011. All five cities with the highest growth in share of rental housing current importance in the country's economy, the paper analyzes how the existing legal framework as well as historic rental laws have affected the rental situation in the city.

\section{RENT CONTROL IN MUMBAI}

LEGAL FRAMEWORK

Rent control has been present in India since the First World War, when it was introduced in order to protect tenants from inflation and evictions (Dev and Dey 2006:2). For several decades after the Second World War rents in Mumbai were regulated as per the Bombay Rents, Hotel and Lodging House Rates Control Act of 1947 , applicable to the erstwhile Bombay province. It was to

Table 4: Comparison of Indian cities with highest and lowest grown in rental housing

\begin{tabular}{|c|c|c|c|c|c|c|c|}
\hline $\begin{array}{l}\text { DISTRICTS } \\
\text { (Urban) }\end{array}$ & \% Rented in 1961 & $\begin{array}{l}\text { Growth in \% } \\
\text { rented between } \\
1961 \text { and } 2011\end{array}$ & $\begin{array}{l}\text { Growth in \% } \\
\text { owned between } \\
1961 \text { and } 2011\end{array}$ & $\begin{array}{l}\text { Ownership Growth } \\
\text { / Rental Growth } \\
\text { 1961-2011 }\end{array}$ & $\begin{array}{l}\text { Work force } \\
\text { participation } 1961\end{array}$ & $\begin{array}{l}\text { Work force } \\
\text { participation } 2011\end{array}$ & $\begin{array}{l}\text { Growth in Workforce } \\
\text { participation } \\
\text { between } 1961 \\
\text { and } 2011\end{array}$ \\
\hline
\end{tabular}

Cities with highest growth in rental housing

\begin{tabular}{|c|c|c|c|c|c|c|c|}
\hline Vishakapatnam & 23 & 106.62 & -31.85 & 0.28 & 33.31 & 35.62 & 6.93 \\
\hline Krishna (Vijaywada) & 46.09 & 14.01 & -11.98 & 0.73 & 34.19 & 37.16 & 8.69 \\
\hline Madhurai & 54.34 & 2.24 & -2.66 & 0.92 & 34.34 & 39.36 & 14.62 \\
\hline Mysore & 48.88 & -3.65 & 3.49 & 1.1 & 31.32 & 38 & 21.33 \\
\hline Tiruchirappalli & 50.95 & -5.08 & 5.27 & 1.19 & 33.25 & 37.06 & 11.46 \\
\hline
\end{tabular}

Cities with lowest growth in rental housing

\begin{tabular}{|c|c|c|c|c|c|c|c|}
\hline Greater Mumbai & 23 & -70.83 & 637.22 & 554.36 & 40.62 & 40.34 & -0.69 \\
\hline Ahmadabad & 46.09 & -71.07 & 249.44 & 40.78 & 31.36 & 34.99 & 11.58 \\
\hline Allahabad & 54.34 & -71.37 & 90.15 & -11.34 & 30.64 & 33.37 & 8.91 \\
\hline Amritsar & 48.88 & -71.93 & 98.01 & -44.71 & 30.71 & 37.06 & 20.69 \\
\hline Agra & 50.95 & -74.47 & 81.33 & -13.43 & 27.91 & 32.08 & 14.94 \\
\hline
\end{tabular}

Source: Census of India

are located in the South. Although there has been a slight decline in Mumbai's workforce participation rate between 1961 and 2011, it is still the highest among the cities selected. In comparison, it has witnessed a significant decline in share of rental housing. It is interesting to note that Ahmadabad and Greater Mumbai, which are among the cities with one of the lowest growth (or highest decline) in share of rental housing, were for a long time governed by the same Rent Control Act. Given the peculiar case of rental housing of Greater Mumbai and its historic as well as

17 To check for heteroskedasticity, we run the Breusch-Pagan/Cook-Weisberg test. We reject the null hypothesis of no heteroskedasticity in case of 'All States' but not for ' 14 Major States'. Given the presence of heteroskedasticity, we make use of robust standard errors. To check for multicollinearity, we compute of heteroskedasticity, we mariance inflation factor (VIF). The VIF is between 1 and 2 for both the runs and therefore indicates
the vility that there are no problems of multicollinearity between regressors. expire in 1973 but was extended repeatedly till its replacement in 1999. Under this Act, rents in rent-controlled properties were to remain at or below standard rents. These standard rents were either determined by the Court or the Controller or they were the rents at which properties were let on the 1st of September, 1940. The Rent Act severely restricted the growth rate of rents and provided minimal increases in rents in case of repairs and improvements undertaken by landlords. In 1999, the Maharashtra Rent Control Act was passed. The Act is applicable to the entire state and brings all the towns and cities in Maharashtra under a single rent control law. According to this Act the standard rents are to be fixed by the court. There 
is no radical departure from the previous Bombay Rent Act. Rents continue to be capped at the standard rent and increases are restricted. Standard rent according to this act is defined as rent determined by the Court or controller under the previous rent acts plus 5 percent ${ }^{18}$ (Dev and Dey 2006); or rent as on 1st October 1987 for properties that were let on or before that date; and rent at which properties were first let for those that were let after this date- and we should note that in such cases the rental at first letting became the standard rent for all time thereafter. The act provides an annual increase of not more than 4 percent from the date of fixation of standard rent. In case landlords make special additions or alterations to the property, rents can be increased by 15 percent of the expenses incurred. The Act also recognizes the practice of pagdi to be legal - that is, paying a cash premium shared by the outgoing tenant and landlord and paid by a new tenant for a transfer of tenancy. Properties under 11 months' leave and license are also exempted from rent controls. The Act protects tenants from eviction on unfair grounds. Wadhva (2002) provides a critique of the Maharashtra Rent Control Act. She states that standard rents are not fixed based on any formulae but are arbitrarily determined by courts and that the rent increases are too low to be a fair rate of return for the landlords. She also states that by distinguishing between different tenanted properties, the Act creates a more segmented rental market. Although the Act exempts leave and licenses from rent control, a 1973 action of the government of suddenly Table 5: Mumbai's real estate break up by tenure (Units) in 2010

\begin{tabular}{|c|c|c|c|c|}
\hline Type of tenure & Total Units & $\begin{array}{l}\text { Other than self } \\
\text { occupied }\end{array}$ & Self Occupied & $\begin{array}{l}\text { Under Rent } \\
\text { Control }\end{array}$ \\
\hline $\begin{array}{l}\text { Banks, Offices and } \\
\text { financial institutions }\end{array}$ & $\begin{array}{l}109,731(4 \%) \\
\{100\}[112]\end{array}$ & $\begin{array}{l}17,248(49 \%) \\
\{16\}[204]\end{array}$ & $\begin{array}{l}64,510(3 \%) \\
\{59\} \quad[119]\end{array}$ & $\begin{array}{l}27,973(6 \%) \\
\{25\} \quad[39]\end{array}$ \\
\hline $\begin{array}{l}\text { Hotels, Malls and } \\
\text { shops }\end{array}$ & $\begin{array}{l}308,211(13 \%) \\
\{100\} \quad[38]\end{array}$ & $\begin{array}{l}6,472(18 \%) \\
\{2\} \quad[80]\end{array}$ & $\begin{array}{l}192,042(10 \%) \\
\{62\} \quad[44]\end{array}$ & $\begin{array}{l}109,697(23 \%) \\
\{36\} \quad[25]\end{array}$ \\
\hline $\begin{array}{l}\text { Amenities and edu- } \\
\text { cational institutions }\end{array}$ & $\begin{array}{l}77,637(3 \%) \\
\{100\}[125]\end{array}$ & $\begin{array}{l}652(2 \%) \\
\{1\} \quad[152]\end{array}$ & $\begin{array}{l}72,796(4 \%) \\
\{94\} \quad[129]\end{array}$ & $\begin{array}{l}4,189(1 \%) \\
\{5\} \quad[62]\end{array}$ \\
\hline Residences & $\begin{array}{l}1,850,761(75 \%) \\
\{100\}[39]\end{array}$ & $\begin{array}{l}9,483(27 \%) \\
\{1\} \quad[54]\end{array}$ & $\begin{array}{l}1,527,287(79 \%) \\
\{82\} \quad[41]\end{array}$ & $\begin{array}{l}313,991(66 \%) \\
\{17\}[29]\end{array}$ \\
\hline $\begin{array}{l}\text { Godown, Storage, } \\
\text { Warehouse }\end{array}$ & $\begin{array}{l}108,361(4 \%) \\
\{100\}[120]\end{array}$ & $\begin{array}{l}1,564(4 \%) \\
\{1\}[209]\end{array}$ & $\begin{array}{l}87,929(4 \%) \\
\{81\}[130]\end{array}$ & $\begin{array}{l}18,868(4 \%) \\
\{18\} \quad[67]\end{array}$ \\
\hline Total & $\begin{array}{l}2,454,701(100 \%) \\
\{100\}[48]\end{array}$ & $\begin{array}{l}35,419(100 \%) \\
\{1\}[141]\end{array}$ & $\begin{array}{l}\text { 1,944,564 (100\%) } \\
\{79\}[51]\end{array}$ & $\begin{array}{l}474,718(100 \%) \\
\{19\}[30]\end{array}$ \\
\hline
\end{tabular}

Figures in ( ) are percentages of the category to the total;

Figures in \{\} are percentage of type of tenure to total.

Figures in [ ] are average size of units in square meters.

Source: Authors' calculations based on MCGM's Property Tax data

18 The inflation rate in India in the last year was 7 percent. bringing the then prevailing leave and licensees under rent control lends little credibility to the promise that this will not happen again, especially when the number of voters affected gets large enough. Thus the act provides very little incentive for landlords to maintain existing or provide new rental housing for poorer people.

\section{EMPIRICAL UNDERSTANDING}

In order to assess the impact of rent control it would be pertinent to examine the spatial patterns and composition of rental tenements in the city. The data used for this purpose has been acquired from the New Property Tax Cell of the Municipal Corporation of Greater Mumbai. It covers approximately 2.45 million units in the formal sector in Mumbai. For each of these units the data set provides the carpet area in sq. mt., the subzone $^{{ }^{9}}$ it belongs to, year of construction, type of current use and type of occupancy - that is, protected under rent control, self occupied and other than self occupied. ${ }^{20}$ Other than self occupied category includes leave and licenses and other similar informal arrangements. Information on slum tenements has not been included in this dataset. Table 5 provides a break-up of units according to different use categories and tenure types in 2010.

Table 5 reveals that in 2010, 19 percent of all properties were protected under rent control. The most predominant use of property has been for residential purposes. In 2010, residences accounted for 75 percent of total units. However, only $17 \%$ of all residences are under rent control. Units under other than self occupied tenure are much smaller in number. Further, their average sizes under all categories are much larger. Looking at the average sizes of residences, we find that other than self occupied (which includes leave and licence) is accommodating only the higher income classes.
19 Subzones are demarcated by the Stamp Duty Ready Reckoner of Mumbai, which is a manual published by the Government providing property prices at a subzone level for the computation of stamp duty. 20 Since the data records current use of property, any time series analysis would require discounting for a change in use in the interim period. A point to consider is that the number of housing units recorded for previous years is likely to be less than the actual number of housing units in those years for three reasons: first, it is likely that houses in the interim have been converted to other more highly priced uses (such as offices) rather than the other way around; second, some buildings may have collapsed in the interim; and third, landlords are permitted to ask tenants to vacate if they can prove in Court that they require the premises for their own use, and some landlords have indeed done this. 
Since this paper seeks to highlight the impact of rent controls on housing markets, it becomes pertinent to examine rental and ownership patterns of residences in Mumbai. Table 6 presents the proportion of residences under different tenures over different time periods. ${ }^{2 t}$

Table 6: Residences in Mumbai by tenure

\begin{tabular}{|c|c|c|c|c|c|c|}
\hline \multirow{2}{*}{$\begin{array}{l}\text { Year of } \\
\text { Construction }\end{array}$} & \multicolumn{2}{|c|}{ Other than Self Occupied } & \multicolumn{2}{|c|}{ Currently Self Occupied } & \multicolumn{2}{|c|}{ Currently Self Occupied } \\
\hline & Carpet Area & Units & Carpet Area & Units & Carpet Area & Units \\
\hline As of 1961 & - & - & $59.3 \%$ & $49.7 \%$ & $40.7 \%$ & $50 . .3 \%$ \\
\hline $\begin{array}{l}\text { Between } 1962 \text { and } \\
2010\end{array}$ & - & - & $96.8 \%$ & $95.3 \%$ & $3.2 \%$ & $4.7 \%^{21}$ \\
\hline As of 2010 & $0.7 \%$ & $0.5 \%$ & $86.7 \%$ & $82.4 \%$ & $12.6 \%$ & $17.1 \%$ \\
\hline
\end{tabular}

Source: Authors' calculations based on MCGM's Property Tax data

This data provides the current use and type of tenure of units along with the year of construction. Although the accurate distribution of tenure type in the previous years cannot be discerned from the data, we attempt to illustrate the approximate situation of self occupied and rental housing in 1961 and compare it with the current period, in order to understand the impact of rent control on tenure type. At present, of all the residential units built in or before 1961, 49.7 percent are self occupied. There are a small number of landlords who have proved in court that they need the premises for their own use, and have thus been successful in evicting tenants enjoying rent control. But this is a small number, and it is safe to assume that the majority of these units have not witnessed a change in their tenure status since the time they were built. Further, at present, of all the residential units built in or before $1961,50.3$ percent is currently under rent control. It is most unlikely that any of the erstwhile self occupied units built on or before 1961 could have undergone a change in tenure and been subsequently brought under rent control. So today's data slightly underestimates the actual number of units that were on rental in or before 1961.

We can infer from Table 6 that the share of units under selfoccupied and tenements protected by Rent Control Act categories

21 There are errors in the dataset regarding the year of construction of units protected by the Rent Control Act. Contrary to our expectation, we found approximately one third units of total units from 1962 to 2010 protected by rent control as having year of construction between 1992 and 2001. Moreover, most of these units concentrated in a few subzones. To investigate this discrepancy, we collected the details of some of the units. We found that units in B.D.D. chawls, which were built in the pre independence period were recorded as being built in the 199os. Site inspections of some other units that were recorded as built after 1990 , revealed that they were actually built in the pre independence period. Thus while the dataset may accurately state the current type of tenure of the building the year of construction has in many cases been incorrectly recorded. was almost equal in 1961. ${ }^{22}$ In stark contrast since then, 96 percent of new residential construction has been for ownership/ self occupied housing while only 3 percent has gone to rental housing. 
the city. Figure 3 provides a closer look at the

Table 7 Distribution of residential units under rent control in Island City island city showing the proportion of residential area under rent control to total residential area in every subzone. It is evident that for several subzones, nearly 100 percent of the residential carpet area is under rent control. These subzones have a large number of old and dilapidated buildings which are expected to undergo redevelopment in the near future. Further, the spatial pattern suggests that much of the low income residential construction was in zones adjoining the spine of railway tracks.

\begin{tabular}{l|l|l|l|l}
$\begin{array}{l}\text { Class interval } \\
\text { (in sq meters) }\end{array}$ & $\begin{array}{l}\text { Number of units in } \\
\text { Island city }\end{array}$ & $\begin{array}{l}\text { Class distribution } \\
\text { of units (\%) }\end{array}$ & $\begin{array}{l}\text { Total carpet area } \\
\text { (in sq. mt.) }\end{array}$ & $\begin{array}{l}\text { Class distribution } \\
\text { of Carpet area (\%) }\end{array}$ \\
\hline $0-10$ & 32,768 & 13 & 254,946 & 4 \\
\hline 10 to 15 & 60,331 & 23 & 761,866 & 10 \\
\hline $15-20$ & 62,664 & 24 & $1,063,547$ & 15 \\
\hline $20-25$ & 29,010 & 11 & 647,185 & 9 \\
\hline $25-30$ & 17,159 & 7 & 468,039 & 6 \\
\hline $30-50$ & 26,187 & 10 & $1,008,766$ & 14 \\
\hline $50-100$ & 21,165 & 8 & $1,453,677$ & 20 \\
\hline$>100$ & 7,902 & 3 & $1,604,358$ & 22 \\
\hline Total & 257,186 & 100 & $7,262,386$ & 100 \\
\hline
\end{tabular}

Source: Authors' calculations based on MCGM's Property Tax data

Figure 4 Subzone-wise average carpet area of residential units under rent control (Island City) ${ }^{23}$

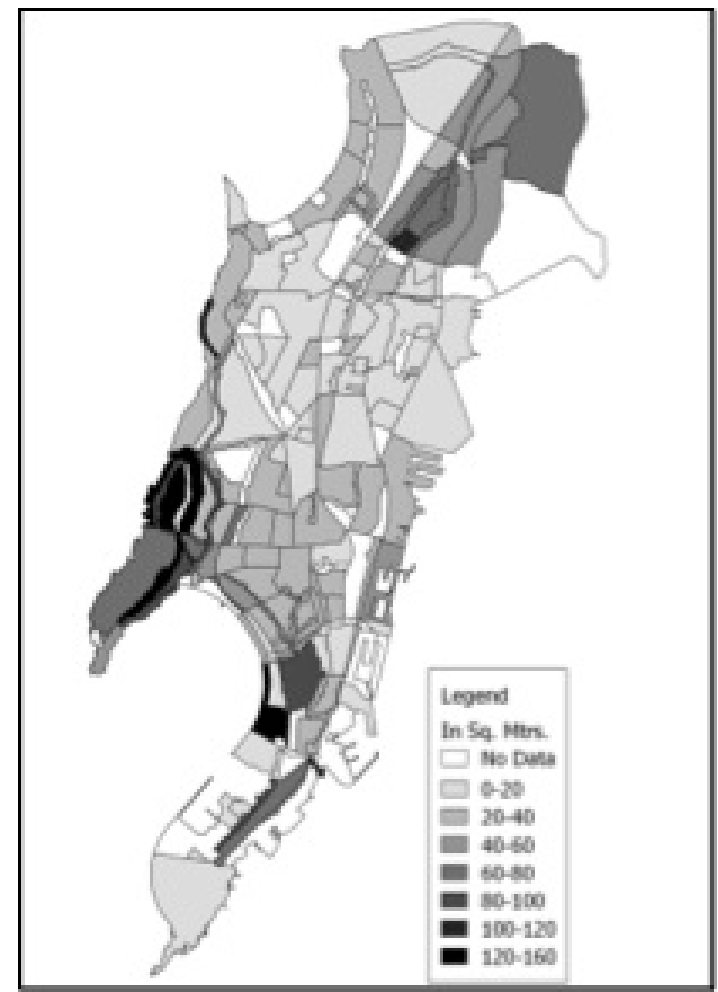

Source: Authors' calculations based on MCGM's Property Tax data

In figure 4 we find a large variation in the average carpet area of rent controlled residential units for subzones in the island city. The average size ranges from 5 sq.mt. to 160 sq.mt. This variation in size and the prevalence of the pagdi system, which has emerged as a response to market forces, makes it safe to conclude that households that enjoy protection under rent control belong to a wide range of income classes.

23 One rent controlled residential unit from a subzone in the northeast of the map has not been considered in the calculation as its inclusion was skewing the average of that subzone by 70 sq.mt.
Table 7 provides a size distribution of the residential units protected by rent control in the island city. In the absence of data on household income and given the existence of the pagdi system as mentioned above, the size of the units provides a proxy for the income classes of the tenants protected by rent control.

Table 7 clearly shows that the median size of units that enjoy rent control protection is less than 20 sq.mt. 79 percent of all rent controlled units are smaller than 30 sq.mt. in area. In terms of total carpet area the corresponding percentages are 29 percent and 44 percent for 20 and 30 sq.mt. respectively. This suggests that while their numbers may be less, the carpet area of units protected by rent control that are large in size is not insignificant. 21 percent of total units under rent control are larger than 30 sq.mt; but this corresponds to 56 percent of the total carpet area. Thus, there is much to be gained by amending the rental laws so that these residences could be freed from protection.

IMPLICATIONS OF RENT CONTROL

The rigid rent controls in the city have led to the deterioration of the existing rental housing stock, "muddled property rights" (Bertaud 2011), and negligible investments in new rental housing. Extremely low returns to landlords have adversely affected their incentives to maintain their properties. In some cases, tenants undertake repairs and maintenance of their premises; but since repairs and maintenance are legally the responsibility of landlords, we find that the condition of most rent controlled properties is dismal. The continuing dilapidation of rent controlled properties led the state government to set up the Mumbai Building Repairs and Reconstruction Board for collecting a repair cess from such 
properties and itself undertaking the necessary structural repairs or reconstruction. Ultimately, the inability of the Mumbai Building Repairs and Reconstruction Board to effectively execute the repairs resulted in the State inviting private developers to redevelop the cessed properties in exchange for certain real estate incentives. However, apart from the damaging effect on the city of some of these incentives, these efforts have only had sporadic success, and many rent-controlled buildings continue to deteriorate.

Rent controls have resulted in unclear property rights, with eviction being difficult and generation succeeding generation of tenants living in the same rent controlled premises. This has prevented transactions of these units in the (formal) market. Informal mechanisms have emerged in the wake of such a lock-in, such as the system of pagdi (or key money). Under this system, for a change of tenancy, the new tenant has to pay a lump-sum amount which is in relation to the market value of the rental property (normally about $80 \%$ of the value of ownership property in the same locality). The sharing of this amount is normally one third to the landlord and two thirds to the outgoing tenant, which is in consonance with the kind of power structures that prevail under the rent act. The tenants have considerably more right over the premises, as they cannot be evicted. Landlords have an option of selling the entire property or building under rent control but obviously find it virtually impossible to find a buyer for their rent-controlled buildings.

Given that investments in rental housing do not yield decent returns in terms of flows or wealth, their significance as part of an investment portfolio has gradually declined. From the empirics, we find that building of formal rental housing has virtually come to a standstill and residential construction is almost entirely for ownership. The scarcity of rental housing has affected affordability. Many households who could have been housed in affordable rental units are now living in slum settlements, within which there is a vibrant rental market. Thus the only beneficiaries of rent controls are the existing protected tenants, who do not now, after 65 years of protection and progress, necessarily all belong to lower income groups.

Leave and license arrangements have been on the rise in the formal housing market since 1999. Although this has led to an increase in tenancies in the city, the numbers are still fairly small and they invariably cater to the middle and higher middle classes. The fact that leave and license has not yet been undertaken at a wider scale can also partly be attributed to the fear - following the experience of 1973 - that the government could, at any point in time, make ad hoc changes in policies that adversely affect leave and licenses. For instance, in 2009, there was considerable alarm following a notice issued by the Municipal Corporation of Greater Mumbai which stated that additional property tax, to the tune of 41.5 percent of the annual rent, would be levied on properties that were given on a leave and license basis (Mhaske 2008). Although the capital value based property tax system that was ultimately introduced by the Corporation did not distinguish between self occupied and leave and license properties, there is no credible way of ensuring that such discrimination against leave and license properties does not take place in the future.

\section{REFORM AGENDA}

It has been known from international experience as well as the literature that rigid first-generation rent controls of the kind present in Mumbai have disastrous consequences for cities. Given the dismal condition of rental housing in the city and its broader impact on the real estate market, there is a dire need to revive the rental housing market. Reforms, therefore, should focus on two objectives: upgrading the existing rental housing stock and incentivizing investments in new rental housing. Each requires a different strategy that takes into account the interests of all stakeholders. International experience also shows that there can be a number of ways of going about reforming rent controls, and successful reforms are those that are implemented gradually. Currently, households belonging to various income classes enjoy protection under rent control. Unfreezing and upgrading of the existing rental housing units could begin by removing protection for those tenant households who do not deserve it. For this, protection may be transferred from the property to the tenant and then a means test may be applied to ascertain the burden that market rent would impose on the tenant and how that relates to her income. Tenants who do not require protection may be divided into those who have paid pagdi after 1999 and have proof for it, those who claim to have paid pagdi but do not have any proof, and those who have not paid pagdi. For those who have paid pagdi and have proof, or where the landlord confirms that pagdi has been paid, protection may continue for a specified number of years from the date of the payment, after which it would cease to exist. For the remaining two classes, protection would be removed. Such 
targeting would free up some amount of rent controlled units and make them available at market rates. In the case of tenants that continue to enjoy protection, policies may suggest arrangements between landlords and tenants for cooperation in the maintenance and up-gradation of the rental units. Policies could also be introduced to provide housing vouchers to the needy tenants so that the landlord does not end up subsidizing the tenants. Also, there should be a movement towards second-generation rent controls, by which rents are raised gradually, at say double the rate of inflation, until they reach a certain, reasonable proportion of market rents. Second generation rent controls would also entail that rents are renegotiated between tenancies.

The caveat here is that collecting information about incomes of all tenants is costly and chances of misreporting are high. The incomes could be ascertained based on information provided by the Income Tax department. However the proportion of individuals paying income taxes is rather low and information about incomes of most families, especially ones belonging to the lower income groups, will have to be gathered on the basis of self reporting, or evidence of assets owned.

For new rental housing, the returns should to be lucrative enough so that it becomes attractive to invest in this rental housing. Past actions of the government both in $\mathbf{1 9 7 3}$ - when the then informal leave and license arrangements were brought under rent control - and 2008 - when the municipal corporation threatened to increase property tax on leave and license properties - demonstrate that its policies are not designed to encourage private rental housing. Encouraging rental housing requires credible policies, backed by law, that no new rental construction would ever be put under rent control and that rental housing is not discriminated against through means such as higher property tax. In addition, any redevelopment should be considered the equivalent of new construction, and as such must have rent control no longer applicable.

Any reform of the existing rent control regime will have to be relatively easy to implement. Repealing or even rationalizing the present rent control system is challenging in terms of political feasibility. There will no doubt be strong opposition from the potential losers, that is, from the tenants protected by the present system, particularly the wealthy and influential ones who cannot pass the means test to qualify for a continued subsidizing of their rents. Here possibly the threat of publicizing their names may suffice to silence their opposition to the change. And international experience suggests that once the vociferous middleclass resistance to lifting rent controls is silenced, opposition crumbles and changes in rent control laws become more easily implementable.

\section{CONCLUSION}

This paper examines the situation of rental housing in India and, focusing on the case of Mumbai, proposes certain reforms for revising the rent control laws in the city. The literature - both theoretic and empirical - suggests that rigid rent controls, also known as 'first generation rent controls' have a devastating impact on the cities' housing market. On the other hand, rental laws that allow for sufficient returns to landlords, in tune with market returns, as well as provide adequate protection to tenants, can boost rental housing. It also finds, through casual empiricism, that for cities in developing countries, stringent rent control laws coincide with a greater proportion of the population living in slums. In the case of India, the share of rental housing has declined drastically from 1961 to 2011. One also perceives a north-south divide; the share of rental housing in the southern parts of the country is distinctly higher than in the northern parts, except for Himachal Pradesh, Uttaranchal and the extreme North-east. To understand the various factors that affect rental housing in India, we run a regression with percentage of rental housing in the urban parts of the state as the dependent variable and urban workforce participation rates, urbanization rates, log population, and log per capita NSDP as independent variables. We run the regression using the data for six time periods first for all states and then for 14 major states. We find that for all states, all variables except urbanization rates have a significant impact on share of rental housing and for 14 major states, all variables are statistically significant.

Having studied the macro-situation, we narrow our focus to the case of rental housing in Mumbai, which witnessed a significant decline in rental housing over the years while housing for ownership flourished. Rental housing in Mumbai is currently governed by the Maharashtra Rent Control Act, 1999. The Act, besides determining fair rent, returns to landlords, and conditions for eviction, also legalizes the practice of pagdi where a new tenant can now officially pay a premium to the outgoing tenant and landlord for transfer of 
tenancy. The Act has several flaws, including inadequate returns to landlords, and as a result has failed to revive rental housing in the city. The rental laws (both the now repealed Bombay Rent Act of 1947 and the current act) have contributed to the deterioration of the existing rental housing stock and decline in creation of new rental housing units. This has ultimately worked against the poor, whom the laws seek to protect, while tenants from higher income groups continue to enjoy a protection they do not deserve.

Finally, the paper proposes reforms in rental laws with the objectives of upgrading the existing stock and incentivizing investments in new rental units. These reforms include removing protection for those who do not require it, making arrangements between tenants and landlords for maintenance of properties, providing housing vouchers to the needy tenants as subsidies, and finally moving towards second generation rent controls.

\section{REFERENCES}

Ballesteros, Marife (2001): Benefits (and Losses) from Rent Control in the Philippines: An Empirical study of Metro Manila, Discussion Paper Series no 2001-23. Philippine Institute for Development Studies, Philippines.

Bertaud, Alain (2011): Mumbai FAR/FSI Conundrum: The perfect storm: the four factors restricting the construction of new floor space in Mumbai. Available at http://alainbertaud.com/AB_Files/AB_Mumbai_FSI_Conundrum_ Revised_sept_2011.pdf

Block, Walter and Edgar Olsen eds. (1981): Rent Control: Myths and Realities: International Evidence of the Effects of Rent Control in Six Countries. Vancouver: Fraser Institute.

Bourassa, Steven C., and Martin Hoesli (2010): Why do the Swiss rent? The Journal of Real Estate Finance and Economics 40(3): 286-309.

Dash, Bharatee B. and Angara V. Raja (2012). Political Determinants of the Allocation of Public Expenditures: A Study of the Indian States, National Institute of Public Finance and Policy (Working Paper No. 2012-101).

Dev, Satvik and Pramila Datta Dey (2006): Rent Control Laws in India: A Critical Analysis, NIUA WP 06-04, New Delhi: NIUA.

Fahmi, Wael and Keith Sutton (2008): Greater Cairo's Housing Crisis: Contested Spaces from Inner City Areas to New Communities. The International Journal of Urban Policy and Planning, 25(5): 277-297.

Furman Center for Real Estate and Policy (2011): Rent Stabilization in New York City, Fact Brief, New York University.

Gandhi, Sahil (2012): Economics of Affordable Housing in Indian Cities The Case of Mumbai. Environment and Urbanization Asia 3(1): 221-235. 
Jenkins, Blair (2009): Rent control: do economists agree? Econ journal watch, 6(1), 73-112.

Kowour, Collins (2012): Controlled Tenancy: A curse or blessing to property investment in Kenya, Task Force on Property and Housing, Mimeo.

Kumar, Sunil (2001): Social Relations, Rental Housing Markets, and the Urban Poor in India, Report to the Infrastructure and Urban Development Department, Department for International Development, London.

Lee, Lik Meng, Yoke Mui Lim, and Yusuf Nor'Aini (2008): Strategies for urban conservation: A case example of George Town, Penang. Habitat International 32(3): 293304 .

Maass, Sue-Mari (2012): Rent Control: A Comparative Analysis, Potchefstroom Electronic Law Journal 15(4): 41-10o.

Makary, S (2002): The Real Estate Sector in Egypt. American University in Cairo Press, Cairo.

Malpezzi, Stephen (1998): Welfare analysis of rent control with side payment: a natural experiment in Cairo-Egypt. Regional Science and Urban Economics 28, 773-795.

Mansour, Salma (2009): New Law Old Problems: The Egyptian Rent Control Dilemma, The Chronicles Mhaske, Pandurang (2008): Shock: BMC plans $41.5 \%$ tax on annual rentals, DNA, May 3, 2008.

Moon, Choon-Geol, and Janet G. Stotsky (1993): The Effect of Rent Control on Housing Quality Change: A Longitudinal Analysis, Journal of Political Economy, 101(6): 1114-1148.

Patel, Shirish (2005): Housing Policies for Mumbai, Economic and Political Weekly, 40(33): 3669-76.

Patel, Shirish (2013): Life between Buildings: The use and abuse of FSI, Economic and Political Weekly, 48(36): 68-74.
Paul, Samuel and Kala S. Sridhar (2013): The Paradox of India's North-South Divide: Lessons from the States and the Regions, Public Affairs Centre, Bangalore.

Pethe, Abhay, Sahil Gandhi, Vaidehi Tandel, and Sirus Libeiro (2012): Anatomy of Ownership and Management of Public Land in Mumbai: Setting an Agenda Using IAD Framework, Environment and Urbanization Asia, 3(1): 203-220.

Phatak, Vidyadhar (2002): Developing Land and Real Estate Markets: The Case of Mumbai Metropolitan Region, reprinted in Mumbai Reader 07, Urban Design Research Institute, Mumbai.

Rajack, Robin Abhay Pethe, Ngau Peter, and Barhate Shrikant (2013): The Political Economy of Urban Land Management: Evidence from Mumbai and Nairobi, Annual World Bank Conference on Land and Poverty, April, 2013.

USAID and TAPRII (2008): Housing Study for Urban Egypt, Final.

Wadhva, Kiran (2002): Maharashtra Rent Control Act 1999: Unfinished Agenda, Economic and Political Weekly, 37(25): 2471-2475.

Werczberger, Elia (1997): Home ownership and rent control in Switzerland. Housing Studies 12(3): 337-353. 